\title{
Legal Regulation of Combating Domestic Violence in Eastern Europe
}

\author{
By Liudmyla Golovko ${ }^{1}$, Olena Uliutina ${ }^{2}$, Iryna Davydovych ${ }^{3}$, Oksana Ilina ${ }^{4}$
}

\begin{abstract}
Considering the increase in the number of cases of domestic violence during the COVID-19 pandemic, it is relevant to study the practices of combating domestic violence, which have become effective in individual countries. The problem of domestic violence is global and various countries have been working to overcome it for a long time. Eastern European countries, especially the Czech Republic, Slovakia and Poland, have made significant progress in combating domestic violence. Therefore, it is appropriate to study their experience. The article examines state policy, national legislation and best practices for preventing and combating domestic violence in these countries.
\end{abstract}

Keywords: domestic violence, legal regulation, protection of women's rights, protection of women from domestic violence, the right to a fair trial

\section{The Experience of The Czech Republic}

In March 2006, the Czech Republic adopted Law № 135/2006 “On Prevention of Domestic Violence", which entered into force in January 2007. Thus, the Czech Republic, as well as other European countries, joined the intention to comprehensively address the problem of domestic violence. The law established the legal framework for addressing the problem of domestic violence by countering domestic violence, including through the temporary eviction of the offender from the common premises with the victim. The law also regulates the provision of direct psychological, social and legal assistance to victims of domestic violence in crisis centers, as well as cooperation between state bodies, bodies of local self-governance and non-governmental organizations involved in combating domestic violence and assistance to victims of domestic violence.

In order to implement the provisions of Law № 135/2006 "On Prevention of Domestic Violence", crisis centers have been operating in the Czech Republic since 2007, providing special social and psychological assistance to victims of domestic violence. If there is a threat of repeated violence, according to the Law, persons who are at risk of domestic violence are provided with judicial assistance by evicting the offender from the premises

${ }^{1} \mathrm{PhD}$., associate professor of the Department of International Law and Comparative Law of the National University of Life and Environmental Sciences of Ukraine

${ }^{2} \mathrm{PhD}$., Associate Professor of the Department of Administrative and Financial Law of the National University of Life and Environmental Sciences of Ukraine, Deputy Dean of the Faculty of Law of the National University of Life and Environmental Sciences of Ukraine

${ }^{3}$ PhD., Associate Professor of Criminal Law Policy and Criminal Law Department of Taras Shevchenko National University of Kyiv

${ }^{4} \mathrm{PhD}$., Associate Professor of Criminal Law Policy and Criminal Law Department of Taras Shevchenko

National University of Kyiv 
shared with the victim. To implement the Law in practice, systematic measures were taken to train social workers, police officers, security guards, judges, doctors, employees of social and legal services for children, administrative commissions, bodies of local selfgovernment and other professionals who have contact with victims of domestic violence, which had a significant positive effect.

On 1 January 2009, Law № 273/2008 “On the Police” entered into force, amending Law № 135/2006 "On Prevention of Domestic Violence", based on the experience gained during of its application. The eviction of the offender from the premises shared with the victim was understood as the performance of the duties of police officers, i.e. it is not a decision issued in administrative proceedings, but is understood as a factual legal action. Thus, according to Law № 273/2008 "On the Police" for the police, the procedure for evicting the offender from the common premises has been significantly simplified, since the police officers are not already forced to make a formal decision with all its components, including justification, as well as there is no need to study compliance with the terms of eviction in the appellate proceedings. With the adoption of the above-mentioned amendment, the risks of procedural offenses were eliminated, and the simplification of the work of the police makes it possible to focus in practice on the correct definition of the qualifications of domestic violence.

The next novelty is the prohibition of the offender to meet with the victim of domestic violence and the prohibition of establishing contact with her or him, abstinence from which is considered as the duty of the offender. \ 141 of the Criminal Code provides for the possibility of mitigating the penalty for murder by taking into account the condition of the murder of a person who has been a victim of domestic violence for a long time.

Action plan for the prevention of domestic and gender - based violence for the years 2019 -2022 helps to systematically address the issue of domestic violence (hereinafter referred to as "the Action Plan"). One of its tasks is to analyze the current state of domestic violence in the country, determine the number of offenses in this area, analyze the effectiveness of legislation aimed at combating domestic violence, as well as analysis of possible changes to it. The Action Plan identified the main objectives and appropriate measures to combat domestic violence. We are talking about the implementation of the main measures in the field of preventing domestic violence, educational sphere, conducting research on this issue, coordinated assistance to victims of domestic violence, introduction of therapeutic programs for offenders who have committed domestic violence, and improving legislative support in this area. The aim of the Action Plan is to implement adequate and effective measures to prevent and end domestic violence so that its victims are not forced to accept the violation of their basic human rights and can live safely, freely, with dignity and without any threats. Analyzing the objectives of the National Action Plan, we can conclude that they reflect the need to combat domestic violence comprehensively, taking into account all causes of domestic violence at all levels: macrolevel (educational activities, information activities, effective social assistance), micro-levels (educational courses on family life, psychological assistance to persons at risk of domestic violence, psychological work with persons who have committed domestic violence).

Measures planned under the Action Plan take into account the specific needs (including prevention, identification and cessation of domestic violence) of all groups of persons at risk of domestic violence, as each group requires an individual approach that takes into 
account all the specifics.

Some provisions of the Action Plan are devoted to children at risk of domestic violence. The implementation of the tasks formulated in this area should improve the legal position of such children, make it possible to provide the necessary psychological assistance, and define at the legislative level the criteria for officials to make decisions on limiting contact with parents who have committed domestic violence.

It is envisaged to ensure the availability of quality services that are able to provide qualified assistance to children and that will take into account the specific needs of children. State support in this area is the creation of specialized institutions for children and assistance in contact with parents - aggressors should be coordinated with the support of centers for people at risk of domestic violence. It is extremely important that such centers take into account the interests and needs of minors. Restrictions, prohibitions or contact with witnesses are currently only partially regulated by Law № 359/1999 "On social and legal assistance to children". Educational activities are aimed at workers who are in direct contact with children who have experienced domestic violence, or make decisions about their rights.

The Action Plan also provides for the provision of therapeutic services to perpetrators of domestic violence. In the Czech Republic, national centers have been established for the systematic work with such persons within the framework of re-socialization programs. We consider such work with family aggressors to be a positive experience. It is necessary to work with perpetrators of domestic violence to change the way they think and behave, in addition to protection of victims. It is clear that such individuals are reluctant to participate in the above therapeutic programs. Therefore, it has become mandatory for persons who have committed domestic violence to participate in this program in the Czech Republic. The effectiveness of therapeutic programs is constantly evaluated in order to determine the most effective work with family aggressors. The aim of the therapeutic programs is to create a network of centers that provide recommendations for the work with persons who have committed domestic violence and to create standards for the work with such persons. The purpose of the Action Plan is also to create a system of continuing education based on interdisciplinary cooperation. The task is mainly to systematically and continuously educate those professionals who, in the performance of their duties, most often come into contact with persons at risk of domestic violence. This applies primarily to doctors, medical staff, teachers, educators, social workers, judges and government officials, including police officers. The aim is to provide workers in these professions with the information needed to recognize domestic violence and to provide qualified assistance and adequate action in the event of domestic violence.

On the basis of the Czech police, there are specialized departments to combat domestic violence, which have been working successfully for a long time. On their basis, it is planned to expand interdisciplinary cooperation between different bodies. The purpose of these specialized groups is to expand this good practice and introduce it into the judicial system. An important tool of their activity is interdisciplinary cooperation and exchange of information and experience between stakeholders, establishing contacts between relevant institutions, expressing their own requirements for the form or quality of work of individual institutions, providing information on the competence and capabilities of individual entities. The creation of such specialized departments is a new practice and, in 
our opinion, this experience of the Czech Republic should be used by all states.

In the Czech Republic, a large-scale innovation campaign was carried out, the aim of which is to change stereotypes and involve the entire public in the prevention and solution of the problem of domestic violence. The ability to recognize the signals of risky relationships and domestic violence and the ability to combat it must be acquired by every student in primary and secondary schools, but this primarily applies to adolescents. Educational programs are also aimed at preventing the process of identifying children with the aggressor so that the child does not adopt a pattern of aggressive behavior from the parent. These educational programs are important, because at school we are taught a variety of information, but not how to choose a worthy marriage partner. The introduction of the issue of domestic violence in the curricula of primary and secondary schools is a truly progressive and important decision.

The issue of ensuring a sufficient number of institutions providing assistance to women who have experienced domestic violence has not been fully resolved. It is planned to expand the existing network of social services for victims of domestic violence. The aim is to provide support for individuals who, after leaving the offender, start their lives with a clean state and without financial resources.

\section{The Experience of Slovak Republic}

The police play a key role in ensuring an effective response to domestic violence. The task of the police is to effectively intervene and provide protection to the victim of violence. According to the law, the Slovak police have the right to arrest and evict a perpetrator of domestic violence from the common premise. The arrest of a perpetrator of domestic violence is, according to scholars (Caragnano, 2018; Garcia-Moreno, 2019; Gracia, 2006; Hornebeck, 2007; Kachur, 2020; Martín-Fernández, 2019; Yara, 2020) a much more effective measure to prevent domestic violence than informational and therapeutic methods, counseling or temporary eviction.

The legal shortcomings of Slovak law still include the lack of competence of police officers (Funta, 2016; Klimek, 2017). Organizations assisting victims of domestic violence have long lobbied for amendments to the Law № 171/1993 “On the Police” of July 6, 1993, in order to expand the powers of the police to prohibit access to common premises for perpetrators of domestic violence if there is a threat to life or health as a result of acts of violence on the model of Austria, Germany, the United Kingdom and the Czech Republic. The original Law on the Police regulated the right to enter the common premise only under $\int 29$, which allowed the opening of an apartment if there was a threat to life or a significant threat to health, or if there was a threat of significant damage to property.

Law № 491/2008 of 24 October 2008, which amended the Law on Police, significantly expanded the powers of police officers. An important change was made mainly in $\ 27 \mathrm{a}$ concerning the power of police officers to evict a perpetrator of domestic violence from the common premise. This paragraph contains comprehensive legal regulation expanding the competence of the police in case of domestic violence. Among the conditions under which a police officer has the right to evict a person who has committed domestic violence from an apartment or house are "clarified circumstances on the basis of which an attack on life, health, liberty or significant humiliation of human dignity can be expected". 
The premise from which the perpetrator is evicted is not only the dwelling itself, but also the territory around it, which the police officer will define precisely. As for the period of eviction, the decision of the police officer is valid for 48 hours from the eviction. In addition to the oral announcement of the eviction order, the police officer is obliged to provide the evicted person and the person at risk of violence with a written confirmation of such a decision. If the violence concerned minors, a copy of the decision is sent to the social welfare authority. The police department is obliged to check the observance of the duty to move out of the common premises. By amending the legislation, the Slovak Parliament has made it clear that it prefers the right to life, health and human dignity of victims of domestic violence to the protection of the right to property and the right to use one's property. Prior to the amendment of the legislation, women who had experienced domestic violence were under enormous pressure. Before these changes, it was the woman who had to leave shared accommodation instead of the perpetrator of violence, which often led to the loss of her social and economic security. The purpose of the amendment to the legislation was to change the entire strategy for the protection of victims of domestic violence. The offender must be obliged to leave the common premise. The police officer gives the aggressor the opportunity to take from the common premise only his personal things and documents, as well as things necessary for the performance of his profession. In Slovakia, a police officer is obliged to inform a person at risk of violence about the possibility of applying to the court for precautionary measures in the form of restriction of the right to use the common premise. The police officer is obliged, if possible, to provide the victim with information about the organizations that provide assistance to victims of domestic violence and contact information about these organizations. Significant positive effect in the fight against domestic violence was given by the development of the Methodology of actions of police officers in cases of domestic violence, which was developed in 2006 within the project "Alterna" by the Slovak crisis center "Touch". All police stations were introduced with this Methodology. Its purpose is to help police officers who have first contact with victims of domestic violence in their work. The assistance of police officers always depends on the stage of the case. In the initial stages of violence, the police can help the perpetrator and the victim of domestic violence to identify the incident and advise the women to resolve it with the help of supporting organizations. At a later stage, when a woman is ready to file a criminal complaint, the police officer is obliged to accept the application and act in the interests of the victim. The Methodology draws attention to the fact that it is undesirable for police officers to make any delays, it is necessary to accept the application on the spot, i.e. not to send the victim of domestic violence to the police station. The Methodology includes in detail the sequence of activities of police officers upon arrival at the place, contact with both parties, the sequence of gathering information and solving problems by police officers. Police officers have been warned about the lack of attention to children. It is necessary to physically separate the victim and the person who committed the crime (a separate police officer communicates with each of them in a separate place) in order to create conditions for a woman to be able to speak more openly. When talking to a woman, it is necessary to adjust the pace and manner of conversation to her mental state, because a woman needs protection, understanding and respect. The victim must be taken seriously. Police officers are obliged to inform the victim not only about their rights, but also about 
the possibility of providing further assistance and support. Part of the methodology is also the obligation to provide contacts to organizations that provide assistance to victims of domestic violence.

The reduction of violent crimes in the family is facilitated by stricter penalties for committing such crimes, enshrined in law. Thus, according to the Slovak Criminal Code of 20 May 2005 № 300/2005, which entered into force on 1 January 2006, domestic violence is punished more severely. The Criminal Code has introduced new qualified crimes that implement the latest scientific advice and international obligations. The new Criminal Code defines a "close person", which makes it possible to punish a wide range of violent crimes committed in the family and, as a result, to provide protection for victims of domestic violence. The new Criminal Code established more severe penalties for violence against a close person, namely the commission of a criminal offense of tyranny of a close person; violence; sexual violence.

According to the Slovak Criminal Procedure Code № 301/2005 of 24 May 2005, the permission of a victim is not required to initiate criminal proceedings against a person who has committed domestic violence. A big positive aspect of the new Criminal Procedure Code is the reduction of time to investigate domestic crimes. Thus, according to $\ 204$ of the Criminal Procedure Code, it is possible to bring a person who has committed domestic violence to court up to 48 hours from the commission of the crime, which significantly reduces the possibility of escape of the perpetrator.

Involvement of the mass media in informing the population about the issue of domestic violence was the goal of the program "Systematic support for the prevention and cessation of violence in the field of coordination and provision of services in crisis intervention centers and groups". To this end, periodic monitoring of the media was planned in relation to their activities aimed at informing the population about the issue of domestic violence.

\section{The Experience of Republic of Poland}

In Poland, as in the Czech Republic and Slovakia, domestic violence is punished more severely than violence against other people. Article 207 of the Criminal Code provides for imprisonment of 3 months to 5 years for physical or mental violence against a close person. If domestic violence has been committed with extreme cruelty, a sentence of 1 to 10 years' imprisonment is imposed (article 207 \2). If, as a result of violence against a close person, that person has attempted suicide, the penalty is imprisonment from 2 to 12 years.

Both the Czech Republic and Poland have passed a separate law aimed at combating domestic violence. In Poland Act on Counteracting Domestic Violence was adopted in June 2010 and entered into force on 1 August 2010. According to this Law, interdisciplinary groups, consisting of representatives of social protection bodies, the municipal commission for solving problems related to alcohol, education, health care and non-governmental organizations, have started their work in each gmina (territorial unit). Interdisciplinary groups are responsible for taking measures to provide joint assistance in individual cases, as well as for coordinating all measures related to domestic violence. Act on Counteracting Domestic Violence introduced a new precautionary measure, which is to evict a person who has committed domestic violence from the common premise if there 
are reasons to believe that the accused person may commit a violent crime against the victim again. Another innovation was the creation of new educational programs aimed at re-education of persons who have committed a violent crime against a member or members of their family.

The law also establishes a procedure for the removal of a person from the family by a social worker if the child's life or health is in danger. The decision is made in conjunction with a police officer, doctor, nurse or paramedic. The social worker is obliged to notify the family court of such a decision within 24 hours of the decision, and the court then decides on the child's future.

Under the Act on Counteracting Domestic Violence, a victim of domestic violence has the right to a free medical examination to determine the cause and nature of the injuries and the right to free medical certificates that can be used as evidence in court proceedings. Medical care for victims of violence is divided into primary and specialized.

The legislation of the Republic of Poland provides for exclusively criminal liability for domestic violence. The responsibilities of police officers in this area include, as far as possible, with the person suspected of committing domestic violence, explaining the criminal liability for domestic violence and explaining to such a person the need to behave in accordance with the law and the rules of social coexistence.

Poland's experience in introducing the so-called "Blue Cards" procedure, which is mainly preventive in nature, is new and quite interesting. According to this procedure, in the event of domestic violence, a police officer initiates the "Blue Cards" procedure by filling out Form "A", which indicates the circumstances of the case. The police officer conducting the proceedings or another local police official explains to the victim of domestic violence possible further actions and provides him / her with information for the victims of domestic violence (the so-called "Blue Card - B" form). The fact that Polish police officers have forms that he/she is obliged to leave to victims of domestic violence is recognized as important. After all, victims of violence at the time of the intervention are in a state of great stress due to the fear and suffering experienced, the presence of police officers, as well as uncertainty about how the situation will end. Thus, it is not to be expected that victims of domestic violence will be able to listen carefully, understand and remember what police officers are telling them in these circumstances.

The victim of domestic violence later has the opportunity to learn all the information she needs in a calmer environment. The "Blue Card - B" form contains a qualified explanation of what is considered domestic violence, who may be its victims, in what forms it most often manifests itself, as well as the types of crimes committed in this area, indicating the cases when criminal prosecution begins under the condition of mandatory submission of a statement by the injured party.

The second part of the "Blue Card - B" form asks the victim of violence to record the course of events: indicate who was the perpetrator when domestic violence happened, what kind of violence happened, how often domestic violence occurred, whether there were witnesses of domestic violence, or whether the victim applied to the competent authorities for termination of domestic violence. The third part of the form contains information on the possibility of a victim to receive help, as well as the location of organizations that can be contacted for help and support. This form is a concrete proposal that strengthens the victims of domestic violence's sense of security and allows them to 
calmly reflect on the situation, as well as seek help if they feel the need.

During the "Blue Cards" procedure, members of the interdisciplinary commission also fill in the "Blue Card - C" forms for a person suspected of being a victim of domestic violence, which develops an individual action plan to help the person and "Blue Card D" in relation to a person suspected of committing domestic violence, where the situation in the family is diagnosed, perpetrator is warned about the responsibility for committing domestic violence and the need to participate in correctional training programs. Most scholars praise Poland's experience in implementing blue card procedure (Yosyfovych, 2012).

The creation of a 24-hour telephone "blue line", through which the victim of domestic violence can immediately notify the police in case of domestic violence, as a result of which the police together with the prosecutor's office immediately take action to eliminate the threat, is also a positive experience.

\section{Conclusions}

Having studied the practice of combating domestic violence in Eastern Europe, we have drawn the following conclusions. In general, the basis of the Action Plans for the Prevention of Domestic Violence in some Eastern European countries is formed by 4 areas, namely: actual assistance to victims of domestic violence; work with perpetrators of domestic violence; educational work for workers who have contacts with victims of domestic violence; and dissemination of information on the state of domestic violence in order to prevent it and change society's attitude to domestic violence.

The value of the Czech experience in combating domestic violence lies in its systematic nature. The main directions of measures include: legal reform on this issue, improvement of law enforcement agencies, development of social services; educational programs, rehabilitation programs. The Czech experience is relevant not only because of the introduction of mandatory psychological programs for perpetrators of domestic violence and educational programs in schools for promotion of friendly tolerant coexistence of family members, but also because of the development of methods for teaching this issue. Slovakia's positive experience is the development of a Methodology for Police Officers in Cases of Domestic Violence, which was developed in 2006 as part of the project "Alterna" of the Slovak Crisis Center "Touch", which was disseminated to all police stations.

The experience of Poland in introducing the Blue Cards procedure, according to which the police officer maintains a savings folder for each family in which violence has arisen and where documents covering the circumstances of the case are accumulated, is original. Thus, in the event of repeated violence, the Polish police officer has all the information about the situation in the family and understands better how he can help the victim of domestic violence. The Polish practice, according to which police officers have special forms with information about the bodies to which a victim of domestic violence may apply for help, is very appropriate. In this case, the victim of domestic violence has the opportunity to study in a calmer environment all the information he or she needs and decide on further steps to protect his or her rights. 


\section{References}

Act of the Czech National Council of 14 March 2006 amending certain acts in the field of protection against domestic violence. (2006). https://www.sagit.cz/info/sb06135

Act of the Czech National Council of 17 July 2008 on the Police of the Czech Republic. (2008). https://www.zakonyprolidi.cz/cs/2008-273

Act of the Czech National Council of 8 January 2009: Criminal Code. (2009). https://www.zakonyprolidi.cz/cs/2009-40

Act of the Czech National Council of 9 December 1999 On the Social and Legal Protection of Children. (1999). Collection of Laws of the Czech Republic № 395/1999 Coll.

Act of the National Council of the Slovak Republic amending the Act of the National Council of the Slovak Republic № 171/1993 Coll. On the Police Force. https://www.psp.cz/sqw/sbirka.sqw?cz=171\&r=1993

Act of the Slovak National Council: Criminal Code № 300/2005. (2005). https://www.zakonypreludi.sk/zz/2005-300

Act of the Slovak National Council: Criminal Procedure Code № 301/2005. (2005). https://ejustice.europa.eu/content_specialised_courts-19-sk-maximizeMS-cs.do?member=1

Caragnano, R. (2018). Violence against women and domestic violence: general framework and overview of the Convention (articles 1 and 2). Athens Journal of Law, 4 (1), 51-66.

Funta, R., Golovko, L., Juriš, F. (2016). Európa a európske právo. Bratislava: Iris.

Garcia-Moreno, C., Amin, A. (2019). Violence Against Women: Where are We 25 Years after ICPD and Where do We Need to Go? Sexual and Reproductive Health Matters, 27, 346-348.

Gender equality - Violence against women and domestic violence. (2020). https://www.legislationline.org/topics/country/10/topic/7/subtopic/25

Government Council for Equal Opportunities for Women and Men. (2019). http://www.vlada.cz/cz/ppov/rada-pro-rovne-prilezlosti/uvod-29829/

Government of the Czech Republic. Action plan for the prevention of domestic and gender-based violence for the years 2019 - 2022 (2019). https://www.vlada.cz/assets/ppov/rovne-prilezitosti-zen-amuzu/Aktuality/AP-DN---grafikaFINAL.pdf

Guedes, A, Bott, S, Garcia-Moreno, C, Colombini, M. (2016). Bridging the gaps: a global review of intersections of violence against women and violence against children. Glob Health Action, 9. https://doi.org/10.3402/gha.v9.31516.

Hornebeck, A., Johnson, B., LaGratta, M., Sellman, R. (2007). The Protection of Women from Domestic Violence Act: Solution or Mere paper Tiger, Loyola University Chicago International Law Review, 4 (2), 273-307

Kachur, V., Protosavitska, L., Zasukha, L., Golovko L. (2020). The Role of Legal Culture in Maintaining Social Stability and Countering Separatist Movements: Case of Ukraine. European Journal of sustainable development, Volume 9, № 1, 294-299.

Klimek, L. (2017). Mutual Recognition of Judicial Decisions in European Criminal Law. Cham: Springer.

Kutsevych, M., Yara, O., Golovko, L., \& Terpeliuk, V. (2020). Sustainable Approaches to Waste Management: Regulatory and Financial Instruments. European Journal of Sustainable Development, 9(2), 163.

Martín-Fernández, M., Gracia, E. \& Lila, M. (2019). Psychological intimate partner violence against women in the European Union: a cross-national invariance study. BMC Public Health, 19, 1739. https://doi.org/10.1186/s12889-019-7998-0

National Strategy for the Protection of Children's Rights 2021-2029. (2021). https://www.mpsv.cz/documents/20142/225508/NARODNI+STRATEGIE+OCHRANY+P RAV+DETI+2021_2029_FINAL.pdf/4d20b44e-a8c5-6882-d46f-a8d0fb7695d5

The Penal Code of Poland. (1997). https://www.legislationline.org/download/id/7354/file /Poland_CC_1997_en.pdf

Yara O., Brazheyev A., Golovko L., Bashkatova V. (2021). Legal Regulation of the Use of Artificial Intelligence: Problems and Development Prospects. European Journal of Sustainable Development, 10 (1), 281-289.

Yosyfovych, D. (2012). Prevention of domestic violence: the experience of the Republic of Poland. (2012). Scientific Bulletin of Lviv State University of Internal Affairs, 3, 387 - 388 